\title{
PINTANDO O MEDO, ESCREVENDO O TEMPO: GOYA E MÁRIO CLÁUDIO
}

\author{
PAINTING FEAR, WRITING TIME: GOYA AND \\ MÁRIO CLÁUDIO
}

Mônica Genelhu Fagundes ${ }^{1}$

\section{RESUMO}

Para além do círculo estrito da crítica de arte, a fase tardia da pintura de Goya, que corresponde aos últimos anos de vida do pintor, já despertou o interesse de biógrafos, romancistas e cineastas. Em flagrante contraste com os retratos de nobres, festas galantes e amenos motivos de tapeçaria que produziu ao longo de sua carreira, a sua obra incorporaria, na velhice, a fantasmagoria, o grotesco, o insólito. Recolhido à Quinta del Sordo, o pintor cobriria as paredes de casa com figuras monstruosas, demônios e bruxas, projetando no espaço familiar uma autêntica iconografia do horror. A partir dessas imagens e em torno delas, Mário Cláudio recria em ficção o final da vida de Goya, transfigurado em D. Francisco no romance Gémeos, de 2004. Por intermédio de uma personagem nossa contemporânea, um estudioso da arte de Goya por ela afetado de modo inesperado, vai-se revelando aí o drama íntimo de um homem em seu enfrentamento com o tempo e a finitude, encenado sobretudo na relação ambígua que se estabelece entre D. Francisco e Rosarito, sua enteada: jovem, perversa e sedutora - reflexo ou inspiração dos vultos nas paredes, a provocar simultâneos desejo e frustração, amor e ódio, fascínio e medo. É o modo de representação dessas dualidades o que nos interessa investigar, em texto e imagem, neste trabalho.

PALAVRAS-CHAVE: Mário Cláudio; Relações interartes; Ekphrasis.

\section{ABSTRACT}

Beyond the narrow circle of art criticism, the late phase of Goya's painting, which corresponds to the last years of his life, has already aroused the interest of biographers, novelists and filmmakers. In stark contrast to the noble portraits, gallant parties and mild tapestry motifs that Goya produced 
throughout his career, his work would incorporate, in old age, the phantasmagoria, the grotesque, the unusual. Cloistered at "Quinta del Sordo", the painter would cover his home walls with monstrous figures, demons and witches, projecting into the familiar space an authentic iconography of horror. From these images and around them, Mario Claudio recreates the end of Goya's life, transfigured into D. Francisco, in the fiction novel Gémeos (2004). Through a character our contemporary, an art scholar who specializes in Goya's painting and is unexpectedly affected by it, the intimate drama of a man in his confrontation with time and finitude is revealed, being staged especially in the ambiguous relationship established between D. Francisco and Rosarito, his stepdaughter: young, perverse and seductive - reflection or inspiration of the shadows on the walls, causing simultaneous desire and frustration, love and hate, fascination and fear. It is the mode of representation of these dualities what we are interested in investigating, in text and image, in this paper.

KEYWORDS: Mário Cláudio; Inter-art Relations; Ekphrasis.

Os relatos desta espécie se incorporam como cicatrizes indeléveis a todo leitor que os mereça. Julio Cortázar

1.

Com esta formidável declaração, comentário crítico de muito mal disfarçado teor confessional, praga agourenta a se rogar e provação que se assume com orgulho qual desígnio digno de anunciação, Julio Cortázar define uma categoria de obras e institui uma comunidade de leitores: dilacerados, feridos, assinalados; membros de uma espécie de estranha seita profana - no que se poderia suspeitar algo de insólito, bem ao gosto de escritor argentino, não fosse o sabermos nós que isto nada mais é do que o resultado (assombroso, é verdade) de certas experiências de leitura.

Não será difícil, portanto, identificarmo-nos e solidarizarmo-nos com o primeiro personagem que o romance Gémeos (2004), de Mário Cláudio, nos apresenta: embora não se trate de um leitor de signos propriamente verbais, o efeito de espelhamento será incontornável. Trata-se de um estudioso de arte, interessado na pintura de Goya, que se instala em Madri a fim de conduzir uma investigação sobre a fase final da obra do pintor espanhol: as chamadas Pinturas Negras - cenas de horror, concebidas originalmente como grandes murais pintados a óleo que adornavam as paredes da casa da Quinta del Sordo, último lar de Goya na Espanha, e mais tarde transferidas para tela, restauradas e doadas ao Museu do Prado. 
É ali, naquele espaço aparentemente seguro do museu, que o pesquisador irá contemplá-las, com consequências inesperadas: a observação das telas parece ser a causa de um estranho mal de que ele passa a sofrer: uma série de ataques de pânico, apresentados no romance como evento trágico: inevitável e decisivo - e em cuja descrição se insinua algo, aí sim, definitivamente insólito:

Se soubesse ele naquela manhã de fins de Julho que o nobre ingresso do Museu haveria de ocupar na sua mitologia privada lugar idêntico ao que na mitologia do Mundo preenchiam a escada angélica de Jacob e a corda apaixonada de Romeu e Julieta, se tanto soubesse ele, é duvidoso que a galgasse de diferente maneira. Do plano térreo que correspondia ao da entrada principal até ao andar onde se poderiam alcançar as obras do seu pintor não mediaria mais do que uma quarentena de degraus, capazes de todavia lhe alterar por completo o rumo da existência, e muito especialmente o modo de a encarar. E o dito espaço vencê-lo-ia a pé, [...] o que traria como efeito que, ao chegar ao destino, lhe batesse o seu tanto o coração, e ao lançar os olhos pela área das suas reflexões, se lhe afigurasse que nunca mais haveria ele de parar. À sua frente, e num caos de linhas que se entrecruzavam e se desfaziam, mesclavam-se as cores dos quadros expostos, um rosto interrogativo, o aceno de um arvoredo, o derrube da bandeira de uma batalha, e nada pertencia a nada, e tudo aquilo que ele mentalmente fora the parecia ter chegado sem remissão ao termo. Era no pavor infrene que se debatia como num mar imenso, destituído de tábua de salvação, entregue ao furor que não lograva identificar senão como a catástrofe final do Universo criado. E moviam-se-lhe à roda, e sem que disso tomasse consciência plena, difusas formas de outras criaturas, semelhantes à que havia sido, mas tão enquadráveis ainda no Mundo, e no seu caixilho de valores rotuláveis, que não davam conta de que ali, e na pessoa daquele visitante, a morte inexoravelmente se implantara. (CLÁUDIO, 2004, p. 41-2)

A enumeração de sintomas que se segue - taquicardia, dispneia, espasmos, suor e frio, tontura e cãibras, caracterizando um severo ataque de pânico - encerra-se com "o medo, sobretudo o medo, o medo, o medo" (CLÂUDIO, 2004, p. 42).

Cenas como essa, em que a contemplação de uma obra de arte desencadeia uma reação desmesurada, que ultrapassa os limites - fluidos, é verdade - da fruição ou do choque estético, para se apresentar como emergência do estranho, afinando-se com o Unheimlich freudiano, essa revelação do terrível no familiar, ou, mais precisamente, essa revelação do terrível como algo estranhamente familiar, não são raras na chamada literatura fantástica. Ela dá conta de espectadores que se descobrem figuras de um quadro, sendo nele aprisionados; ou que são mortos por personagens pintados sobre uma tela ou fixados em papel fotográfico; além de outros tan- 
tos, mais afortunados estes talvez, que testemunham imagens plásticas em metamorfose, como a revelar monstros em sua problemática visualidade.

Na narrativa de Mário Cláudio, não se caracteriza uma tal ruptura da lógica dita realista, mas textualiza-se o insólito na dissolução de valores, sentidos e referências balizadoras de tempo, espaço e identidade. As repercussões físicas e fisiológicas do drama psíquico e moral enfrentado pelo personagem do pesquisador vêm apenas comprovar o poder de violência e alteração de certas imagens sobre aqueles que as olham: como se elas pudessem de fato abrir feridas e se incorporar como cicatrizes nos seus espectadores.

Esse trabalho da imagem, tão dramatizado pelo viés do fantástico, encontra uma interpretação no campo da filosofia da arte nas reflexões do teórico francês Georges Didi-Huberman, que pensa o olhar como ação de abertura e transformação, e uma relação que se estabelece em via de 'mão dupla'.

Olhar seria compreender que a imagem é estruturada como um diante-dentro: inacessível e impondo sua distância, por próxima que seja - pois é a distância de um contato suspenso, de uma impossível relação de carne a carne. Isso quer dizer exatamente - e de uma maneira que não é apenas alegórica - que a imagem é estruturada como um limiar. Um quadro de porta aberta, por exemplo. Uma trama singular de espaço aberto e fechado ao mesmo tempo. Uma brecha num muro, ou uma rasgadura, mas trabalhada, construída, como se fosse preciso um arquiteto ou um escultor para dar forma a nossas feridas mais íntimas. Para dar, à cisão do que nos olha no que vemos, uma espécie de geometria fundamental. (DIDI-HUBERMAN, 1998, p. 243.)

Na sua trágica constatação de ser um nada de coisa e um muito de potencialidade de significação, a imagem se instaura como este limiar interminável, como uma porta aberta que não se pode atravessar, e que, portanto, vai assumir a visualidade e o sentido tenso de um vão: não atravessado, não preenchido - perigosíssimo vazio que a imagem revela e que repercute para além dela, como cisão a se insinuar naquele que ousa contemplá-la. Aí se insidiam os monstros.

Cindido e à mercê deles se perceberá o pesquisador que deixamos em meio a um ataque de pânico na sala do Prado, diante das imagens de Goya. No futuro de muitas outras crises semelhantes à desse dia fundamental (e fundador de uma escritura, já veremos), ele recusará o diagnóstico científico de clínicos e psiquiatras, e reconhecerá o seu mal como uma espécie de fantasmagoria - má palavra, talvez, para referir o que seria uma recepção estética assombrada das Pinturas Negras: "De uma questão de presenças, e da difusa energia do artista que viera estudar, é que entendia tratar-se" (CLÁUDIO, 2004, p. 115): como se as cenas pintadas por Goya guardassem cristalizado, mas muito vivo, o horror que as teria gerado, re- 
ativado diante do olhar do pesquisador. Como se de algum modo as telas pudessem abrir um canal de comunicação entre um pintor envelhecido do século XIX e um crítico de arte do século XXI, e os seus medos - do isolamento, da impotência, da proximidade da morte. "Em certos momentos, supor-se-ia ser esta aniquilação o termo de uma agonia que fora vivida já" (CLÁUDIO, 2004, p. 95): passado de um outro re-materializado no presente de um eu dilacerado.

Como a carregar, além de si mesmo, um Goya nas costas, o pesquisador se dedicará à escrita da biografia do pintor. Não mais, porém, segundo o protocolo de objetividade que pauta o discurso acadêmico, mas numa expressão cindida que representa - e não resolve - a sua problemática conexão com o artista espanhol. Compondo a maior parte do corpo do romance Gémeos, a "biografia" constitui-se como um relato em fragmentos, cujo foco narrativo oscila entre a primeira e a terceira pessoas, como a encenar uma hesitação: aquele contato suspenso, aquela dupla distância de que fala Didi-Huberman: o jogo do próximo e do longínquo. Entre a biografia como exercício ficcional e a fictícia autobiografia, compostas a partir de informações autênticas da vida de Goya e de uma certa leitura de sua obra plástica, vão-se desenvolvendo e complementando níveis diversos de invenção, e projetando-se a posição de um eu que é e não é Goya, que a ele se quer colar ou que busca compreender o seu mistério e a inquietude que provoca, num sondar o outro que é tentativa de compreensão (e apaziguamento) de si mesmo.

\section{2.}

Essa geometria de cisões, porém, não se limita no romance a uma reedição do tema do duplo que repercute como modelo de estrutura narrativa, mas vai concretizar-se no espaço construído como o cenário actante que é a casa da Quinta del Sordo, representada como uma espécie de projeção arquitetônica de uma subjetividade genial, delirante, perturbada e angustiada, tendo suas paredes cobertas com figuras grotescas, fanáticos, bruxas e demônios. Uma autêntica iconografia do insólito e do horror a constituir o espaço familiar. Perfeita apresentação do Unheimlich.

A fictícia autobiografia de Goya, recriada por Mário Cláudio a partir da perspectiva afetada, já se sabe, daquele pesquisador de arte nosso conhecido, compreende justamente o período de composição dos catorze murais que constituem o conjunto das Pinturas Negras. A narrativa se inicia com a chegada de Dom Francisco - como o pintor aparecerá transfigurado no romance - à Quinta del Sordo. Ali Goya tinha de fato ido viver em 1819, segundo dados biográficos. Estava já velho e arrastava a sequela de uma doença que o acometera anos antes, deixando-o quase completamente surdo - dado este que o nome da propriedade (Quinta del Sordo: Quinta do Surdo) inscreve como irônica coincidência ou golpe de vidência: o surdo a que fazia referência originalmente não era Goya, mas um antigo vizi- 
nho da estância. Acompanhavam o pintor a sua governanta viúva - que é outro modo de dizer a sua amante - Dona Leocádia e a filha dela, Rosarito.

Como sugere o romance, porém, a companhia das duas não bastava para livrar Dom Francisco do estado de isolamento em que se percebia, certamente agravado pela surdez e pela debilidade progressiva do envelhecimento. Na sua solidão, ia-se sentindo cada vez mais ameaçado, tomado por um medo indefinido que tentaria expurgar por meio da pintura.

Ele percorria as quadras da nova casa, e o frio da serra mordia-lhe os ossos emperrados. Assustavam-no as paredes nuas, alternando com a órbita esvaziada das janelas que davam para a paisagem de galhos desfocados, dos quais a chuva não parava de pingar. [...]

E remexia na ideia o caldeirão das substâncias que esconjurassem os espíritos maus, óleos pastosos sobre os estuques, amplos volumes entenebrados, uma nuvem de sinistros visitantes. Não tardaria a que se deitasse a confeccionar as poderosas tintas, todo um Inverno de pigmentos surrados, de trapos e de carvões, de asfixias e de adormecimentos, de mastodontes que na noute se esboçavam, mas que iam permanecendo, comparsas em quem tropeçava, que o levavam de rastos para o seio dessas broncas chusmas a que pertenciam. (CLÁUDIO, 2004, p. 29-30)

Pode parecer absurdo que uma pintura de tom sombrio e enigmático, tematizando o grotesco e a bruxaria, fosse concebida como modo de esconjurar o mal e dominar o medo, mas, pelo menos para o Dom Francisco de Mário Cláudio, tratava-se disso mesmo: por meio daquelas imagens perturbadoras, procurava o pintor encontrar formas que pudessem expressar o desconhecido que o atormentava, traduzir em visualidade as suas angústias, os seus terrores e pesadelos, que de outro modo seriam tanto mais inquietantes.

A artimanha lembra a astúcia dos antigos navegadores e cartógrafos dos séculos XV e XVI, que povoavam os "mares nunca dantes navegados" e as terras recém-descobertas com toda sorte de monstros marinhos e seres grotescos. Por ameaçadores que fossem, permitiam preencher com a imaginação o vazio sempre mais arriscado do absolutamente desconhecido. Ser capaz de representar o perigo era já um primeiro modo de conhecê-lo, de domesticá-lo. Num artifício semelhante, D. Francisco parece querer trazer para dentro do seu domínio - o seu espaço doméstico e a sua arte de pintura - os terrores que tanto o afetavam. Parece, assim, perfeitamente justa a metáfora com que o pintor descreve sua nova casa, logo ao chegar à Quinta del Sordo: "Tinham escancarado as gelosias, o que conferia ao edifício algo de navio que desarvoradamente singrasse a caminho do mar." (CLÁUDIO, 2004, p. 19). No campo semântico da náutica, convém lembrar, um navio desarvorado é um navio sem mastros, desorientado, portanto. Talvez tenha sido em busca de um rumo e de algum controle que Goya/D. Francisco temerariamente executaram as Pinturas Negras, trazendo para o bojo do "navio" os terrores anunciados na tempestade. 
A narrativa de Mário Cláudio vai acompanhar a produção dessas imagens, num trabalho paralelo e cíclico de interpretação e criação, leitura e escritura, segundo o qual se vai partir das telas de Goya para construir um universo, uma intriga e um caráter para o personagem Dom Francisco, que por sua vez servirão, em movimento reverso e complementar, para dar um suporte de realidade (ainda que inventada), uma intenção e um sentido às pinturas. Ao longo do texto, nós leitores vamos acompanhando o processo de invenção de Goya/Dom Francisco, testemunhando os fatos e tomando conhecimento de impressões que teriam levado à criação de cada mural, desde corriqueiras cenas domésticas a profundos dramas existenciais. E assim as Pinturas Negras vão ganhando corpo, transpostas pela escrita.

Há algo de muito lúdico na leitura desse romance, em que a todo momento se suspeita uma imagem conhecida de Goya a surgir recriada no papel, tendo fantasiadas sua origem, sua história e sua significação. Ao final, estamos como que dentro da casa da Quinta del Sordo, junto com um pintor que conhecemos muito melhor do que por meio de qualquer catálogo de exposição, com uma intimidade antes impensada. E de fato este adentrar-lhe a morada é um modo de perscrutar a mais funda humanidade da sua arte.

\section{3.}

Não há um consenso entre os pesquisadores de Goya acerca do sentido de conjunto das Pinturas Negras. No romance de Mário Cláudio, porém, elas são apresentadas como obsessivas variações em torno de um mesmo problema: a inexorabilidade do tempo, que leva à decrepitude e à morte. Tema nuclear do livro, este inimigo invisível, temido e incontrolável é aí representado agudamente por meio do contraste que se estabelece entre o velho pintor Dom Francisco e sua jovem enteada Rosarito. Entre eles se delineia uma relação de fascínio e horror, amor e ódio, desejo e frustração, perversão e culpa. "Que pode porém um velho diante da juventude que desabrocha?” (CLÁUDIO, 2004, p. 38), indaga retoricamente o pintor, enclausurado na sua impotência, numa formulação-chave do texto, que vai ganhar ao longo do romance uma série de interpretações visuais, baseadas em imagens de Goya.

A constatação da decadente sexualidade de Dom Francisco torna-se trágica e patética diante da efervescência erótica de Rosarito, e o horror não declarado deste ilícito e impossível desejo que atormenta o pintor encontra via de escape no território inconsciente dos sonhos, em que a menina surge transfigurada como bruxa que tem as feições da Duquesa de Alba, antiga amante de Goya. Se os Caprichos do pintor - uma série de oitenta gravuras de sentido grotesco e satírico - foram qualificados por muitos dos seus críticos como cenas de delírio, aqui muito adequadamente é uma daquelas lâminas que servirá a Mário Cláudio para imaginar o pesadelo de Dom Francisco. 


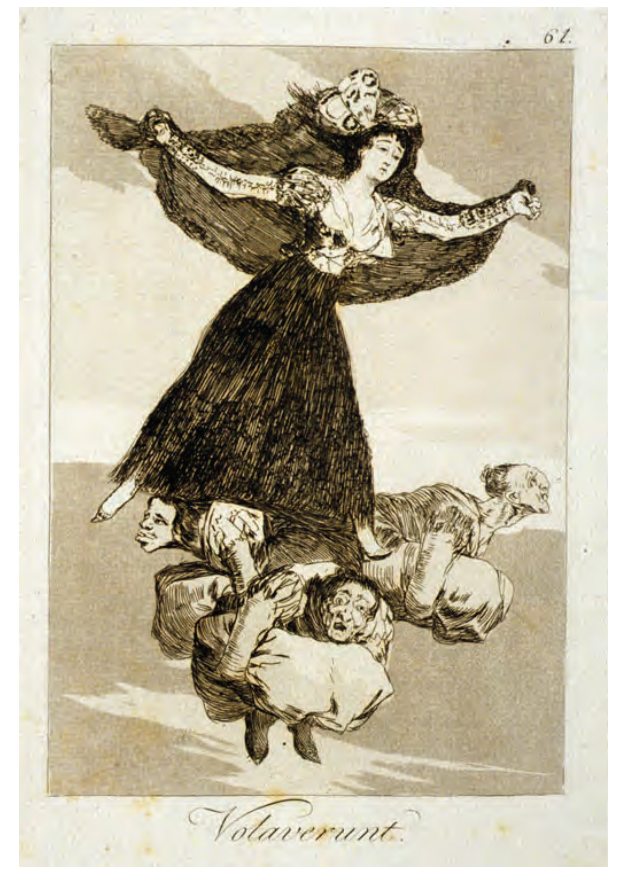

Trata-se do Capricho 61 - Volaverunt [Eles terão voado], assim apresentado em Gémeos:

Deparava-se-me a menina diante do esboço de uma corja infernal que uivava enquanto a ia transportando pelos céus, e sobre as espáduas aladas, um trasgo animado das piores intenções. Aparecia-me ela completamente branca, revestida de alto a baixo de uma farinha que se lhe acumulava em papa na comissura dos lábios, brandindo a chave dourada do Paraíso onde eu jamais penetraria. E escancarando olhos de morta que de supetão ressuscitasse, lançava-se a discursar, e de modo a que a compreendesse pelo movimento dos lábios, "Bons dias, Dom Francisco, os rins já funcionam?, e o catarro soltou-se?, e ainda lhe dói o joanete?, e o seu cu, Dom Francisco, arde-lhe hoje como deve arder o cu dos macacos?, será que lhe não serviram o purgante, Dom Francisco?" (CLÁUDIO, 2004, p. 27)

Não será preciso muito esforço para perceber as implicações sexuais da imagem, ressaltadas pela transposição ekfrástica operada por Mário Cláudio: a figura voluptuosa, que se abre ao olhar, carregada em voo por seres infernais, cuja visualidade cindida sugere ambiguamente uma deusa e uma ave amaldiçoada; a farinha branca que se acumula em papa na comissura dos lábios; a chave de um Paraíso que se oferece apenas para se negar - figura que concretiza metaforicamente aquele sentido da imagem como interminável limiar de expectativa e impenetrabilidade que se ergue diante de quem o contempla como vazio torturante e arriscado. Toda esta carga erótica de que se investe o corpo feminino, representação de Rosarito no inconsciente de Dom Francisco, vai gerar, no entanto, um efeito de flagrante contraste com a decrepitude do pintor, humilhado pelo ícone mesmo do seu desejo, no irônico discurso de cuidado que o expõe como corpo decrépito, imagem do grotesco. 
Virá agravar a angústia de Dom Francisco a descoberta de que Rosarito se insinua para os empregados da Quinta, despindo-se diante deles e encorajando-os a fazerem o mesmo diante dela. Flagrando-a numa dessas ocasiões, o pintor a agride com violência, deixando-a prostrada, evocando a cena gravada num outro Capricho de Goya: a lâmina 9 - Tântalo.

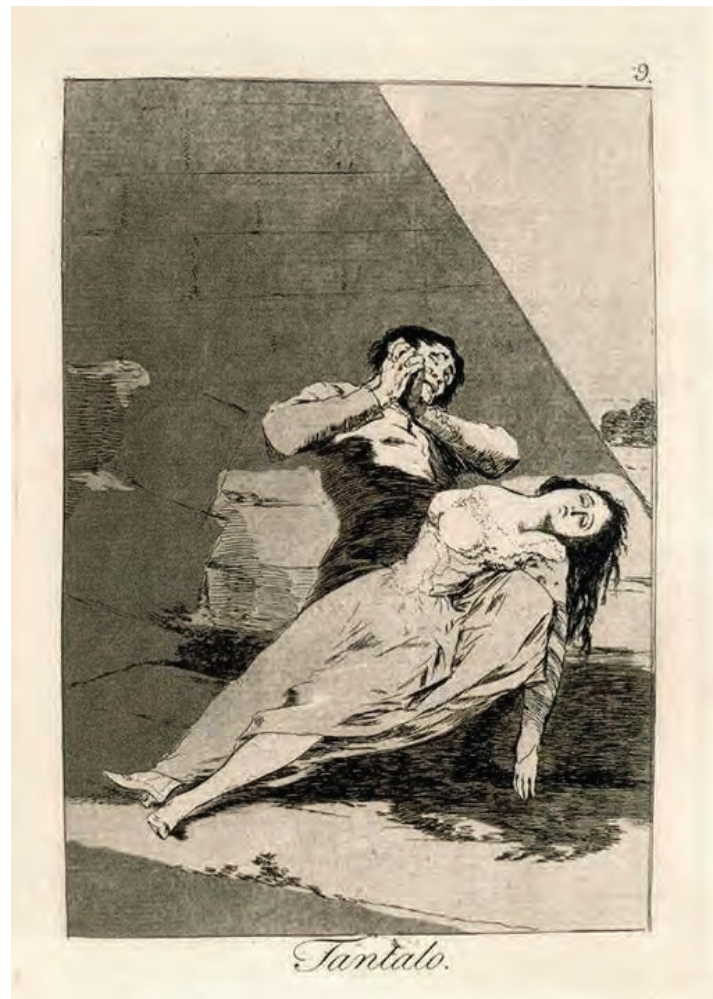

Não tive pulso em mim então que não a arrancasse do banco, a sacudisse pelos ombros, lhe aplicasse as bofetadas, menos da força que da intenção, em que se me desoprimia a alma. E não era nela, mas em mim mesmo, que se desatavam as lágrimas, nem dela, mas de mim mesmo, que se escapava este pranto, "Ai, Virgem do Pilar, ajuda-me que perdi a razão!" Abateu-se Rosarito, semelhante a um espantalho desengonçado. (CLÁUDIO, 2004, p. 38-9)

Tântalo, criminoso mitológico acusado de roubar o néctar e a ambrosia dos deuses para oferecer aos homens, teve como punição o ser eternamente atormentado pela sede e pela fome: a água do rio em que ficava imerso até o pescoço recuava a cada vez que ele tentava bebê-la; o galho carregado de frutas sobre sua cabeça se afastava a cada vez que ele tentava alcançá-las. Na gravura de Goya, o velho tem sobre os joelhos o corpo inerte, mas voluptuoso de uma jovem. Ela está, porém, rígida demais, morta talvez, ou, metaforicamente, alheia e inalcançável ao desejo desesperado do velho, que não pode excitá-la.

Na trama do romance de Mário Cláudio, a relação de Dom Francisco e Rosarito funciona como motivação a várias das Pinturas Negras, que darão ao suplício do desejo interdito - "trama singular de espaço aberto e 
fechado ao mesmo tempo" (dizia Didi-Huberman), geometria de cisões uma interpretação grotesca ou criminosa. Mais uma vez revela-se assim a conexão entre o tema do livro e a concepção de imagem que subjaz a um romance que, sem transgredir o seu pacto ficcional ou fazer concessões à plena liberdade de criação que o gênero promove, se ensaia também como crítica de arte. O conhecimento de pintura e os exercícios de interpretação sobre a pintura de Goya contribuem para a construção harmoniosa da trama e das relações entre as personagens que nela atuam.

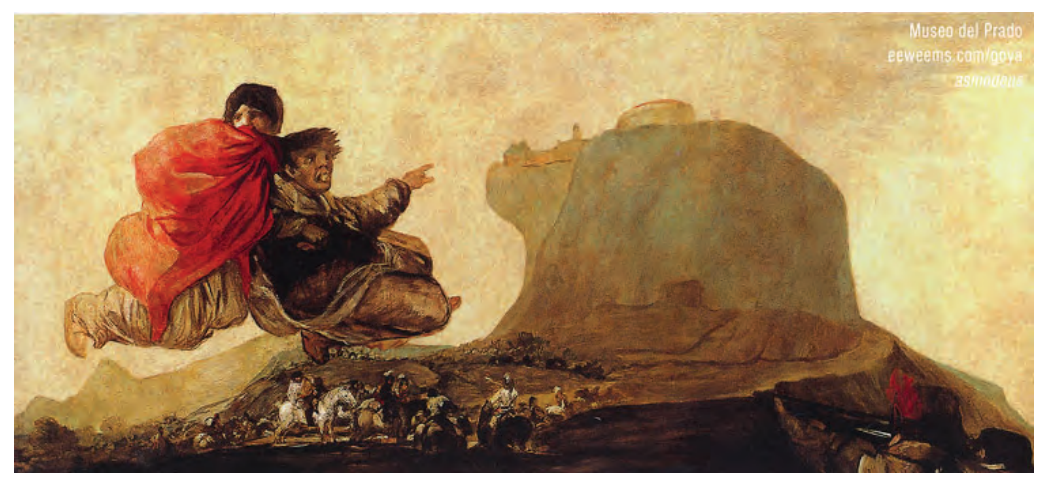

Assim o mural que representa o demônio Asmodeu, raptor de virgens, pintado à semelhança de um dos camponeses grosseiros que, no tormento de Dom Francisco, pretendem tomar-lhe Rosarito:

Na parede do comedor, situada à direita da janela, aproveitando talvez a ventania que por aí entrava, e que haveria de enfunar as vestes dos seus figurantes, reproduziu Dom Francisco o grande demônio Asmodeu, guloso de virgens como nenhum outro. E surgiu o malvado como um grosseirão, pesado de concupiscência, arrebatando a sua donzela pelos ares. Olham-nos de baixo as míseras populações, ignorantes dos desígnios infernais, e não falta quem avance de espingarda, a tentar abater os que voam. Rosarito consente que a raptem, envolvida no manto vermelho, e a mirada que dirige ao seu passado ninguém saberá dizer se é de angústia ou de euforia. (Cláudio, 2004, p. 79)

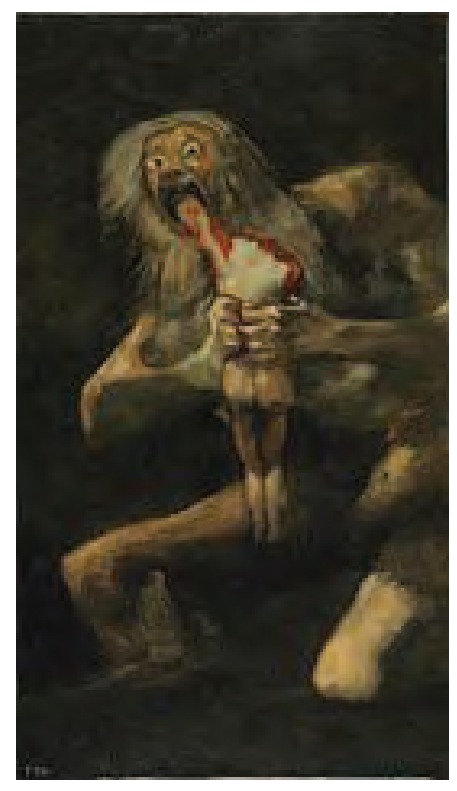


Assim também o Saturno devorando seu filho, que, no romance, para além de encarnar a monstruosidade do tempo que tudo consome, retoma o sentido original do mito do pai que não tolera ser vencido pelo filho, enfatizando o matiz de vingança aí presente, mas lhe agrega um evidente peso de violência erótica: um se não te posso ter por bem, te devorarei. A vítima do titã pintado por Goya tem as formas de um corpo feminino, jovem e atraente, de curvas bem marcadas, como é bem marcada a tensão das mãos crispadas que o agarram. Em flagrante contraste, está a decrepitude do gigante, com a cabeleira branca desgrenhada, os olhos esbugalhados de terror, como num delírio, a musculatura atrofiada, os membros descarnados, só pele e osso. E na mancha negra que encobre o seu sexo parece anunciar-se, em lugar de falo, a anamorfose de um rato, a denunciar grotesca impotência e vileza.

A pintura é o modo de Dom Francisco expurgar os seus demônios, que ali irão habitar:

prossegui nos empastes daquele Saturno que me assombrava os dias. Ampliava-se o velho, louco como nunca, por dentro de mim e para além do meu inferno. [...]

E diante de Rosarito muito mais tarde, sofrendo o irresistível ímpeto com que se ia evadindo a menina do cárcere a que a condenara, erguera-se-lhe de súbito, a flanquear uma das portas do piso inferior da casa da Quinta, a envergadura de Saturno omnipotente. // O velho deus escancarava os olhos sanguinolentos, e toda a monstruosidade do Planeta se quedava neles reflectida. E apertava entre os dedos o corpo hirto de Rosarito, pronto a esquartejá-la antes de a levar à boca. (CLÁUDIO, 2004, p. 39/44)

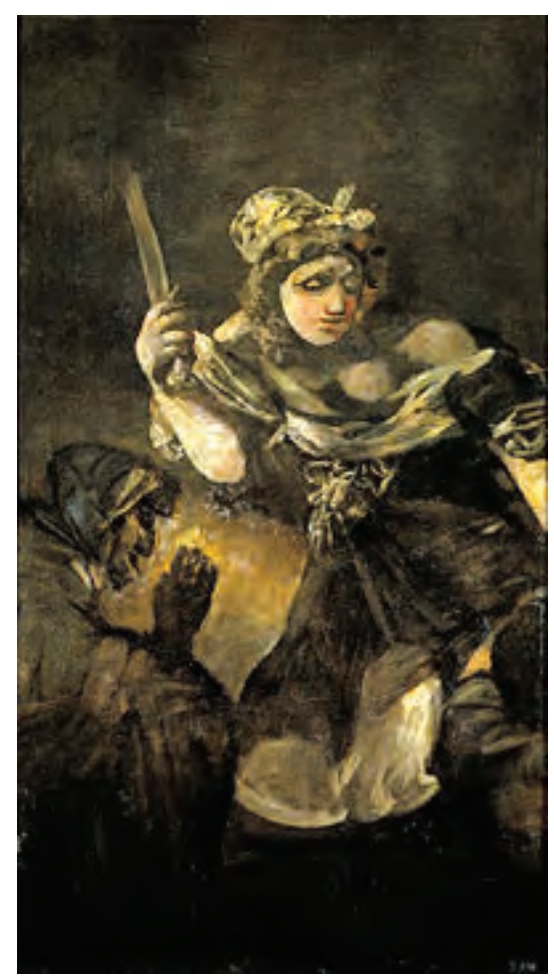


A sublimação pela pintura não serena, porém, Dom Francisco, que projeta também nos murais a punição por suas imaginadas transgressões. Surge assim, em contraponto ao Saturno, Judite e Holofernes, retomando a história bíblica da jovem heroína que finge ceder à sedução do general para então cortar-lhe a cabeça com um cutelo, cuja conotação fálica é explicitada na pintura de Goya e no texto de Mário Cláudio que a relê: "Levantava então Judite o alfanje de degolar borregos, e fazia-se tudo de treva, e apenas o lume ardia, arfando como um moribundo." (CLÁUDIO, 2004, p. 45-6). Mais uma vez encontram-se aí o êxtase erótico e a morte, binômio que ronda todo o livro. E curiosamente a figura masculina é excluída da cena pelo enquadramento da pintura. De Holofernes vê-se apenas o que parece ser o alto da cabeça, prestes a ser cortada. Uma Judite de colo sedutor, marcado pelo decote e pelo volume das vestes, ocupa o centro do quadro, com a criada ajoelhada ao lado, em prece piedosa ou abençoando o ato da ama.

É às bruxas, porém, que Dom Francisco acabará por associar Rosarito e Dona Leocádia, que ele suspeita ser uma espécie de alcoviteira ou celestina - para ficar no espaço cultural espanhol - da menina. Convence-se de estarem as duas possuídas e compactuadas com o demônio. E imagina-as num Aquelarre, ou Sabbath, cercando o "Grande Cabra", que surge na imagem como ameaçadora silhueta.

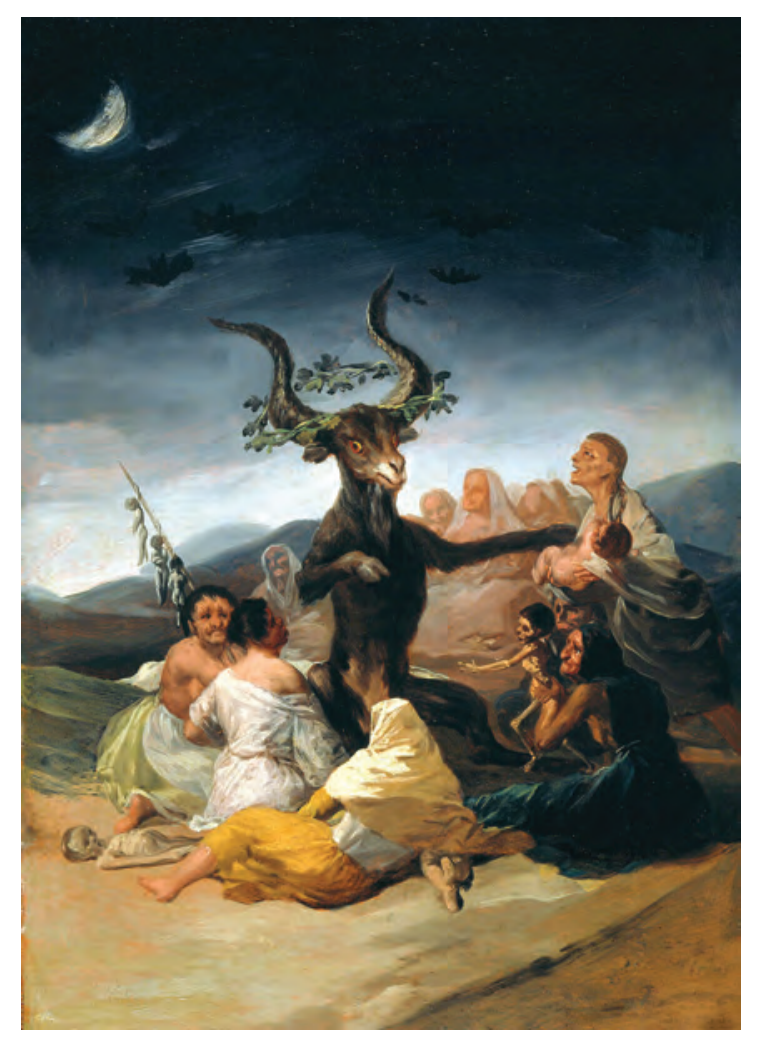

No outro canto da tela, está a figura de uma jovem, afastada das outras mulheres e distinta delas, mais nova e pálida, coberta de negro e com as mãos protegidas por um regalo. Poderia ser Rosarito, numa espécie de rito de iniciação. 
Altas horas, revolvendo-se no convívio, entrecortado de sono, com os monstros grosseiríssimos que o habitam, jurará Dom Francisco pressentir Dona Leocádia e Rosarito, escapulindo-se ambas por uma das portas traseiras, transportando ossadas com terra agarrada, embrulhadas num xaile, sapos mortos, ceroulas que o velhote retirou, maculadas nos fundilhos, ovos chocos, coisas assim. E segredando-se incentivos e cumplicidades, tomarão as duas o caminho de um dos cerros vizinhos, tropeçando não raro em seus próprios vestidos, rindo muito da escapadela. Subirá a lua então entre nuvens que se abrem e fecham por acção de certos corpos translucentes, e não ladram os cães, nem cantam os galos, só o sopro se escuta de um raposinho amedrontado. E chegam à anfractuosidade daquela rocha, e nela se entronizará o Grande Cabrão, rodeado por um mulherio em escarcéu desenfreado, confabulando de moléstias deletérias e de amores transtornados, cosendo e descosendo bainhas, mordendo-se na inveja do cuidado que o senhor a que obedecem dispensa a cada qual. (CLÁUDIO, 2004, p. 98)

Mais do que o aspecto sobrenatural, chama atenção nesta reunião de bruxas imaginada por Dom Francisco o sentido de um conluio, de uma conspiração. Isolado em sua velhice, em sua surdez, em sua impotência, o pintor se sente ameaçado pelos seus próprios impulsos e pelos interesses dos outros que o cercam: a perversa Rosarito, a gananciosa Dona Leocádia. E, sobretudo, pelo tempo, que lhe corrói o corpo e o enche de terrores de uma morte próxima, a todo momento anunciada. Parece ser este medo do desconhecido, que não tem imagem para si, este vazio, o que pintor tenta representar recorrendo ao insólito dos demônios e bruxas.

$\mathrm{Na}$ sufocante solidão amedrontada, o personagem de Mário Cláudio só encontra consolo num cão, Dom Beltrán, que aparece na Quinta e se torna seu companheiro.

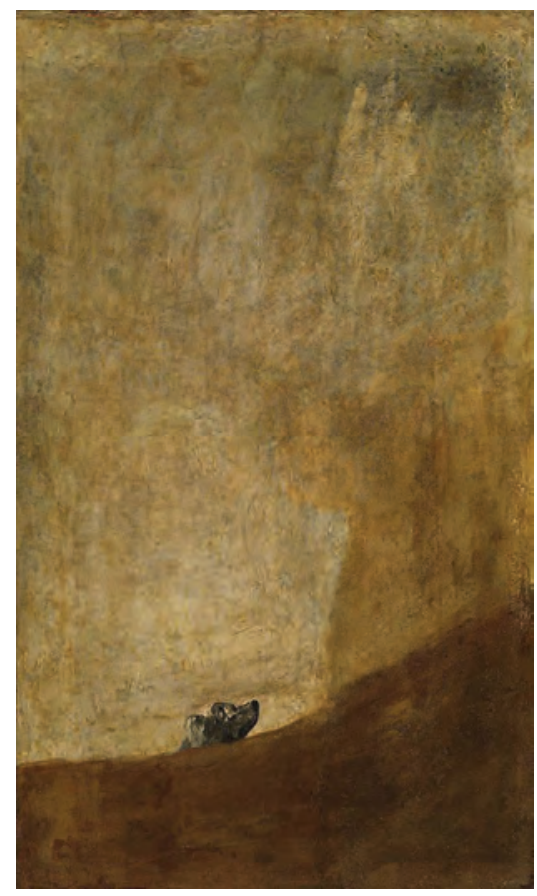


A figura é inspirada no mural Cão semi-enterrado, única pintura de Goya que aparece como imagem plástica de fato no romance Gémeos, como capa do livro, e transposta verbalmente nas suas linhas quase finais: "Numa das paredes do corredor, e no silêncio abafado, luta Dom Beltrán, o cão, com o terrível pesadelo, porfiando por se libertar daquela duna imensa onde mais e mais se vai enterrando." (Cláudio, 2004, p. 133) Entre Sabbaths, Saturnos devoradores e Asmodeus sequestrando virgens, a imagem da cabeça do cãozinho nas dunas poderia parecer curiosamente inofensiva, terna e familiar. Será esta, no entanto, provavelmente, a mais triste e terrível das Pinturas Negras. Nenhum demônio, nenhuma bruxa, nada grotesco: um cão apenas, em sua insuportável solidão diante da morte. A areia o vai cobrindo e o sol já se desintegrou em cinzas no alto da tela. Ele tem o focinho levantado, como fazem os cães para o vento e para os seus mestres. Mas não há ali ninguém. O que o cão testemunha, semienterrado no corte entre areal e céu, suspenso nesta última salvação talvez possível, é só o vazio que invade o espaço pintado como inquietante luminosidade. O tempo, sabemos, fará desaparecer o corpo, deixando apenas a linha da cicatriz.

Será absurdo reconhecer no cão um autorretrato do pintor? Ao apossar-se da sua Quinta, preparado para terminar ali a vida, o Dom Francisco de Mário Cláudio identificava a "cor de barrocal" como "marca primeira da paisagem" (CLÁUDIO, 2004, p. 16-7) e sentia que "Um ventinho agudo retalhava-[lhe] o pescoço". Não hão de ser mero acaso as semelhanças dos cenários e de suas personagens: a cor da duna em que o cão se enterra e a da quinta que se anunciava para Dom Francisco um ataúde ("Que significa de facto a morada a que nos habituamos, meus senhores, senão o ataúde que nos há-de guardar?" (CLÁUDIO, 2004, p. 19); e as virtuais decapitações do cão e do pintor. Não há de ser, portanto, impossível pensar na imagem de Goya como cristalização do sentido que o escritor português dá à narrativa do final da vida do pintor espanhol: sozinho e impotente diante do horror da morte próxima, mas a contemplá-la com seu olhar atento, alucinado e genial. A gravar na tela e no tempo a cicatriz de uma ferida que talvez se abrisse outra vez, diante de um outro olhar atento e também alucinado. Ou assim pode imaginar a ficção.

\section{REFERÊNCIAS BIBLIOGRÁFICAS}

CLAUDIO, Mário. Gémeos. 2 ed. Lisboa: Dom Quixote, 2004.

CORTÁZAR, Julio. Do conto breve e seus arredores. In: ---. Valise de cronópio. São Paulo: Perspectiva, 2006. P. 227-237.

DIDI-HUBERMAN, Georges. O que vemos, o que nos olha. Trad. Paulo Neves. Rio de Janeiro: Ed. 34, 1998.

FREUD, Sigmund. (1919) O Estranho. In: História de uma neurose infantil. Edição Standard Brasileira. Vol. XVII. Rio de Janeiro: Imago, 1969. 
HUGHES, Robert. Goya. Trad. Tuca Magalhães. São Paulo: Companhia das Letras, 2007.

Recebido para publicação em 21/05/2017

Aprovado em 17/09/2017

\section{NOTAS}

1 Professora de Literatura Portuguesa da Universidade Federal do Rio de Janeiro. Sua área de investigação são os estudos interartes, especialmente diálogos com as artes visuais estabelecidos pela Literatura Portuguesa moderna e contemporânea. 